\section{Lisbon Magnetic Observations}

Mr. DE Brito Capello, Director of the Lisbon Magnetic Observatory, having addressed to me several interesting results having reference to the notice of his observations which appeared in NATURE, vol. xiii. p. $30 \mathrm{I}, \mathrm{I}$ am anxious to communicate them to your readers.

With reference to the movement of the declination magnet from $8 \mathrm{~A} . \mathrm{M}$. to 2 P.M. Mr. Capello gives me the following mean values for each year from $185^{8}$ to 1875 :-

\begin{tabular}{lllr|rrrr}
1358 & $\ldots$ & $\ldots$ & 8.74 & 1867 & $\ldots$ & $\ldots$ & 6.15 \\
1859 & $\ldots$ & $\ldots$ & 10.54 & 1868 & $\ldots$ & $\ldots$ & 7.17 \\
1860 & $\ldots$ & $\ldots$ & 10.11 & 1869 & $\ldots$ & $\ldots$ & 8.42 \\
1861 & $\ldots$ & $\ldots$ & 9.00 & 1870 & $\ldots$ & $\ldots$ & 10.83 \\
1862 & $\ldots$ & $\ldots$ & 7.84 & 1871 & $\ldots$ & $\ldots$ & 10.60 \\
1863 & $\ldots$ & $\ldots$ & 7.65 & 1872 & $\ldots$ & $\ldots$ & 9.45 \\
1864 & $\ldots$ & $\ldots$ & 6.94 & 1873 & $\ldots$ & $\ldots$ & 8.22 \\
1865 & $\ldots$ & $\ldots$ & 6.61 & 1874 & $\ldots$ & $\ldots$ & 7.23 \\
1866 & $\ldots$ & $\ldots$ & 6.19 & 1875 & $\ldots$ & $\ldots$ & 6.09
\end{tabular}

These quantities, Mr. Capello remarks, show the maxima I 859.8 and $1870^{\circ} 9$, and the minimum $1867^{\circ} \mathrm{I}$, agreeing very nearly with the epochs of maximum and minimum sun-spots.

It also appears as if the mininium had been reached again last year, the mean oscillation $\left(6^{\prime} \circ 0\right)$ being less than in 1867 . This agrees with the conclusion derived by me from the Trevandrum observations, and communicated to the French Academy of Sciences last year. Dr. R. Wolf had previously (as I now find ${ }^{x}$ ) concluded from his sun-spot observations that the minimum would probably appear in $1875-6$; and he considers we have now one of the short periods, which his tables of sun-spots show may be expected every 80-90 years. My own conclusion to the same effect (that we have now a short period) was founded on a consideration of the magnetic observations. The last short period was that from the maximum $1829^{\circ} 7$ (shown by Arago's observations) to that of 1837.5 (shown by Gauss's observations), an interval of rather less than eight years. If we may take $1875^{\circ} 5$ as the epoch of the present minimum, then the interval from the last is nearly nine years. As the interval from the minimum of Arago (I824.2) to the next was nearly $9^{\circ} 2$ years, we find a space of nearly forty-two years from the last short period to this one. Should this hold for the rext naximum it will occur about $1879^{\circ} \mathrm{o}$.

Mr. Capello has obtained the interesting result that the curve showing the mean diurnal disturbance of the vertical magnetic force is the exact inverse of that for the mean diurnal disturbance of declination at Lisbon; a movement of the north pole of the declination magnet towards the west corresponding to one downwards of the south pole of the balance needle. It appears also that the difference of sign in the temperature coefficient for the balance magnet due to changes of the compensation bar from brass to zinc and zinc to brass, on which a remark was made in NATURE, vol. xiii. p. 302, does not affect the results for the diurnal variation, each year giving the same nean law of a minimum vertical force between I I A.M. and noon, and a maximum near 5 P.M. whatever the sion of the temperature coefficient. It appears also that the results at Lisbon are confirmed by those obtained at Coimbra, ninety miles to the north. JoHn AILAN Broun

\section{The Early History of Continued Fractions}

THE reviewer in NATURE, (vol. xiii., p. 304), very properly points out that the first mathematician who used continued fractions was Cataldi, and not Lord Brounker, as is still often stated.

To this fact I drew attention in a pamphlet, published in 1874, not then knowing that De Morgan had done the same many years ago. There is, however, in connection with the same subject, another historical fact almost equally interesting, which few in this country seem to be aware of, and which therefore it may be desirable to bring before your readers.

Daniel Schwenter, a proíessor at Altdorf, in the first quarter of the seventeenth century, made use of the present well-known process for expressing the ratio of two integers as a continued fraction, and calculated the convergent, exactly in the mode at present followed. He does not indeed seem to have written as we now do the actual continued fraction obtained in any case, but the process of repeated division, and the mode of finding the convergents were most fully described and exemplified by him. ${ }^{1}$

The following, therefore, seems to be, in few words, the early history of continued fractions :-

I. Cataldi published, in 1613 , his discovery that the square root of an integer can be expressed as an interminate continued fraction, e.g.,

$$
\sqrt{18}=4+\frac{2}{8}+\frac{2}{8}+\frac{2}{8}+\ldots .
$$

2. Schwenter, almost certainly without knowledge of what Cataldi had done, published in 1636 the mode of changing an ordinary fraction into a continued fraction with unit-numerators, and of calculating therefrom convergents to the given fraction, e.g.,

$$
\frac{I I 7}{233}=\frac{I}{I}+\frac{I}{3}+\frac{I}{6}+\frac{I}{4}+\frac{I}{2}
$$

3. Brounker, very probably in igno:ance of what had been done by Cataldi and Schwenter, made the discovery that

$$
\frac{\pi}{2}=\frac{I}{I}+\frac{I}{2}+\frac{4}{2}+\frac{9}{2}+\ldots .
$$

which was published by Wallis in 1655 ("Aritlmetica Ininitorum" p. I8I), along with a tolerably complete theory of continued fractions in general.

The necessary details bearing on these three main facts will be found in a painstaking work by Prof. Favaro, "Notizie Storiche sulle Frazioni Continue," Roma, 1875, or in shorter form, in a school "programme" by Dr. Giinther, "Beiträge zur Erfindungsgeschichte der Kettenbruicke," 1872.

That Cataldi, Schwenter, and Brounker, starting from totaliy different points should ali light on the continued fraction form, and that it should be twice (perhaps neariy thrice) lost, are certainly strange facts, forming a curious chapter in the history of scientific discovery.

Firigh School of Glasgow THOMAS MUIR

\section{The Dry River-beds of the Riviera}

Mr. R. E. Bartlett (Nature, vol. xiii. p. 406) asks for some theory to account for the existence of the broad stony riverbeds of Piedmont. He instances the Paglione at Nice, which is indeed the merest rudiment of a river for the greater part of the year. But if Mr. Bartlett will wait, not so much for the snows on the Maritime Alps to be melted, as for the rainy weeks of autumn to come again,

$$
\begin{aligned}
& \text { Quum fera diluvies quietos } \\
& \text { Irrital amnes, }
\end{aligned}
$$

he will see that that now despiciable river aunually flows with a vehemence and a volume worthy of its size. Many a dry and insignificant torrent-bed in the neighbourhood of Nice swells during the rainy season to a torrent indeed; the thoroughness with which they then drain the adjacent slopes is amply sufficient to explain their existence and their appearance when their "occupation's gone." HENRY T. WHARTON London, April 2

\section{The Flame of Common Salt}

HAVING been much interested in the progress of the investigations concerning the blue flame of common salt when thrown into a coal fire, I made the following experiments, by which $I$ came to the conclusion that the origin of the blue flame is due to the presence of copper, which occurs in nearly every coal as an ingredient of the pyrites.

According to "Bercelius," by agency of the blow-pipe, small

I See "Daniel Schwenter, Deliciæ physico-mathematicæ," Nürnberg, 7636 , p. III. "M. Daniel Schwenter"s Geometrix practice novæe et auctæ Libri IV." durch Georgium Andrem Bocklern, Nürnberg, 1657, p. 43I. 